\title{
Use of the Additive Based on Amorphous Silica-Alumina in the Adhesive Dry Mixes
}

\author{
Loganina VI* and Zhegera CV \\ Department of "Quality management and construction technologies" Penza State University of Architecture and Construction, Russia
}

\begin{abstract}
This article proves the possibility of using amorphous aluminosilicate as a modifying additive for the adhesive dry mixes. The data is given on the microstructure and chemical composition of the amorphous aluminosilicates. This article described the character changes in the rheological properties of cement-sand mortar, depending on the percentage of additives. The model of cement stone strength using synthetic additives in the formulation is illustrated. The results of physical and mechanical properties of tile adhesive made on the basis of the developed adhesive dry mix formulations are described.
\end{abstract}

Keywords: Dry mixes; Amorphous silica-alumina; Plastic strength; Tile adhesive; Cement

\section{Introduction}

One of the priorities of modern building materials science is the development of effective building materials. To regulate the technical and operating characteristics of dry mortar formulation is administered in their structure various modifying agents [1-8].

Most of the modifiers used in the formulation of domestic dry construction mixtures, are coming from abroad, which significantly increases the cost of dry mixes and makes production dependent on imported supplies. In this regard need to the development of domestic of production the modifiers. As the modifying agent of domestic production is proposed to use synthetic zeolites as structure-forming and water-retaining additive for dry construction mixtures.

Previous studies have confirmed the efficacy of synthetic zeolites as a modifying agent for cement and lime dry mixes [9-19].

\section{Materials and Methods}

We received amorphous silica-alumina their precipitation from the solution of aluminum sulfate of technical $\mathrm{Al}_{2}\left(\mathrm{SO}_{4}\right)_{3}$ with the addition of sodium silicate followed by washing the precipitate with water. Then, the resulting precipitate was dried.

Adhesive strength was determined by testing the samples fon stretching by tearing instrument ИР 50-57 with traverse moving speed $35 \mathrm{mk} / \mathrm{c}$.

Plastic strength or yield stress of the mixture was determined by plastometer KP-3. Plastic strength determined by the formula:

$$
\eta=\tau=\tau_{0}=k * \frac{P}{h^{2}},
$$

Where $\eta$ : Plastic strength;

$\tau$ : Shear stress;

to: Yield stress;

$\mathrm{k}$ : coefficient depending on the value of the vertex angle of the cone; for the metal cone with an apex angle of $30^{\circ}-\mathrm{k}=1,116$;

P: The weight of the movable part of the device (load);

h: Depth of immersion of the cone in the mortar mixture.

\section{Research Results}

Additive based on amorphous silica-alumina is a powder of white color with a high specific surface component $S_{s p}=68.6 \mathrm{~m}^{2} / \mathrm{g}$. Microstructure and chemical composition of the amorphous aluminosilicate examined via analytical scanning electron microscopy (Figure 1 and Table 1).

It was found that the microstructure of the synthetic additives is characterized by particles of round shape, dimensions 5,208-5,704 $\mu \mathrm{m}$, but the particles are present also oblong form, size 7.13-8.56 $\mu \mathrm{m}$.

Analyzing the data in Table 1 revealed that predominate chemical elements $\mathrm{O}, \mathrm{Si}, \mathrm{Na}, \mathrm{S}$, and $\mathrm{Al}$ in chemical composition amorphous aluminosilicates-containing $60.69 \%, 31.26 \%, 24.23 \%, 18.69 \%$ and $8.29 \%$ respectively. The preponderance of this element has a positive

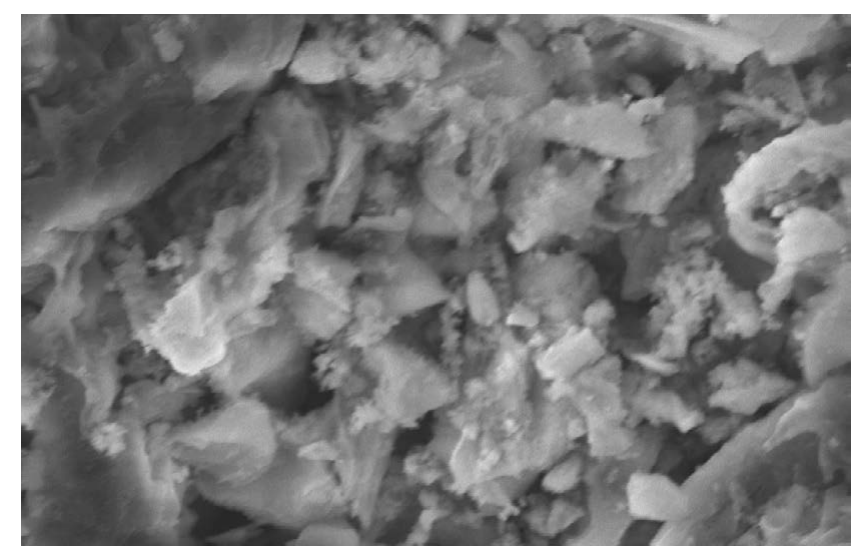

Figure 1: Microstructure of amorphous aluminosilicate.

*Corresponding author: Loganina VI, Department of "Quality management and construction technologies" Penza State University of Architecture and Construction, Russia, Tel: +7 841 256-08-06; E-mail: loganin@mail.ru

Received June 30, 2017; Accepted August 02, 2017; Published August 12, 2017

Citation: Loganina VI, Zhegera CV (2017) Use of the Additive Based on Amorphous Silica-Alumina in the Adhesive Dry Mixes. J Material Sci Eng 6: 361 doi: 10.4172/2169-0022.1000361

Copyright: (c) 2017 Loganina VI, et al. This is an open-access article distributed under the terms of the Creative Commons Attribution License, which permits unrestricted use, distribution, and reproduction in any medium, provided the original author and source are credited. 


\begin{tabular}{|l|c|c|c|c|c|}
\hline \multirow{2}{*}{ Content } & \multicolumn{5}{|c|}{ Chemical elements additives weight, (\%) } \\
\cline { 2 - 6 } & $\mathbf{O}$ & $\mathbf{N a}$ & $\mathbf{A l}$ & $\mathbf{S i}$ & $\mathbf{S}$ \\
\hline Maximum & 60.69 & 24.23 & 8.29 & 31.26 & 18.69 \\
\hline Minimum & 36.73 & 8.61 & 1.10 & 7.92 & 0.68 \\
\hline
\end{tabular}

Table 1: Chemical composition of the admixture.



Figure 2: Kinetics set plastic strength cement-sand mortar: 1 - with a synthetic additive ( $30 \%$ by weight of cement) 2 - with a synthetic additive ( $20 \%$ by weight of cement), 3 - with the use of synthetic additives ( $10 \%$ by weight cement), 4 - a control sample (without the use of synthetic additives).

effect on the formation of cement stone structures with used synthetic additives.

The effect of amorphous aluminosilicate was investigated to modify the rheological properties of cement-sand mortar. For research we used Wolski portlandcement M400, and sand deposits of Ukhta in the ratio 1:2. In Figure 2 given results of these studies are presented.

Analysis Figure 2 showed that the introduction in the cementsand mortar the additive based on amorphous aluminosilicate leads to higher values of plastic strength aged $20 \mathrm{~min}$ after curing compared to the control sample is 1.9-4.7 times (depending on the content the additives). Thus, the sample aged for 20 minutes from the beginning of solidification has strength was $0.0061 \mathrm{MPa}$, while the sample with using of amorphous aluminosilicate ( $20 \%$ by weight of cement) $-0.023 \mathrm{MPa}$.

It is obvious that, when introduced into the formulation of cementsand mortar additives based on amorphous aluminosilicate period of hardening cement-sand mortar reduced, that is, the admixture has a water-holding capacity.

On the basis of mathematical research and experimental design [20] constitute the model of cement stone strength. The factors affecting the change in strength of cement paste were investigated size of the specific surface additives $\left(\mathrm{x}_{1}\right)$, the percentage of synthetic additives $\left(\mathrm{x}_{2}\right)$ and the percentage of plasticizer Kratasol PFM $\left(\mathrm{x}_{3}\right)$. After the analysis of the experimental data and the exclusion of insignificant coefficients of the regression equation, the model of cement stone strength expressed by the formula:

$$
\begin{aligned}
& y=24,477+2,6433 \cdot x_{1}-1,0383 \cdot x_{2}-1,3303 \cdot x_{3}-4,5958 . \\
& \left(x_{1}\right)^{2}-3,3495 \cdot\left(x_{2}\right)^{2}-2,0564 \cdot\left(x_{3}\right)^{2} \\
& +0,69375 \cdot x_{1} x_{2}+0,36875 \cdot x_{1} x_{3}+0,31875 \cdot x_{2} x_{3}
\end{aligned}
$$

Physical and mechanical properties of tile adhesive (includes the

\begin{tabular}{|l|c|c|}
\hline \multicolumn{1}{|c|}{ Name of indicator } & \multicolumn{2}{|c|}{ Value of the indicator } \\
\cline { 2 - 3 } & Designed composition & $\begin{array}{c}\text { The prototype } \\
\text { (no additives) }\end{array}$ \\
\hline Density of the $\mathrm{mix},\left(\mathrm{kg} / \mathrm{m}^{3}\right)$ & 1800 & 1670 \\
\hline The correction time, $(\mathrm{min})$ & 20 & 30 \\
\hline Water retention, $(\%)$ & $97.8-99.3$ & $95.0-97.0$ \\
\hline Slipping tile no more than, $(\mathrm{mm})$ & 0.3 & 0.5 \\
\hline Frost resistance of tile adhesive & $F 50$ & $F 50$ \\
\hline Frost resistance of contact zone & $F_{\text {к3 }} 50$ & $F_{k 3} 50$ \\
\hline Adhesion strength, $\mathrm{R}_{\text {adg }},(\mathrm{MPa})$ & болеe 1.4 & 1.1 \\
\hline Cohesive strength, $\mathrm{R}_{\mathrm{kog}},(\mathrm{MPa})$ & 2.2 & 1.6 \\
\hline Adhesion strength in shear, $(\mathrm{MPa})$ & 0.92 & 0.6 \\
\hline
\end{tabular}

Table 2: Physical and mechanical properties of tile adhesive.

M400 Portland cement, sand fractions (mm) 0.63-0.315: 0.315-0.16 in a ratio of (\%) 80: 20, amorphous aluminosilicates, plasticizer Kratasol PFM and redispersible powder Neolith P 4400) are given in the Table 2.

\section{Conclusion}

Determined, that the use of a binder with additive amorphous aluminosilicate leads to higher values the plastic strength in early and late periods hardening. The given model of cement stone strength in the presence of synthetic additives and plasticizer Kratasol PFM proved the efficiency of the use of amorphous aluminosilicate as a modifying additive. This modifying additives a structure formation and improves the physical and mechanical properties of tile adhesive.

\section{References}

1. Loganina VI, Zhernovsky VI, Sadovnikova MA, Zhegera KV (2013) The addition of aluminosilicate-based cement systems. Eastern European Journal of advanced technologies 5: 11-68.

2. Loganina VI, Petukhova NA, Gorbunov VN, Dmitrieva TN (2009) Prospects for the manufacture of organo-mineral supplements on the basis of domestic raw materials. Proceedings of the higher educational institutions Building, pp: 936-939.

3. Jenni A, Holzer M, Zurbriggen M, Herwegh M (2005) Influence of polymers on microstructure and adhesive strength of cementitious tile adhesive mortars. Cement and Concrete Research 35: 35-50.

4. Stark U, Reinold M, Muller A (2003) Neue Methoden zur Messung der Korngrobe und Kornform von Mikro bis Marko.Weimar pp: 11369-1380.

5. Taramasso M, Perego G, Notari B (1980) Proceedings of the 5th International Conference on Zeolites (Ed.L.V.C.Rees) 2: 40.

6. Mirsky YV, Mitrofanov MG, Dorogochinskiy AZ (1964) New adsorbentsmolecular sieves. Grozny: Chechen-Ingush, p: 385.

7. Doroshenko YM, Shanah JI (1989) Processes of structure and properties of cement stone with polymeric modifiers. 15 Szilikatip esszilikattund konf SILICONF R.I Budapest, pp: 273-276.

8. Yiqing $F$, Lianzhang $C$ (1991) Effect of aqueous boric acid (H3B03) treatment on catalytic performance of HZSM-5 zeolite catalysts. Shiyou Jiagong 7: 44.

9. Loganina VI, Zhegera KV (2014) Evaluating the effectiveness of the use of synthetic aluminum silicates in cement systems. Academic Gazette UralNIIproekt RAASN, pp: 384-387.

10. Loganina VI, Ariskin MV, Karpova OV, Zhegera KV (2015) Evaluation of crack resistance of the finishing layer based on adhesive dry mixture with synthetic aluminum silicates. Building Materials, pp: 1086.

11. Loganina VI, Makarova LV, Tarasov RV, Sadovnikova MA (2014) Composition limy binder with the use of the synthesized alumiosilicates for dty construction blends. Advanced Materials Research 977: 34-37.

12. Loganina VI, Makarova LV, Tarasov RV, Zhegera KV (2014) The composition cement binder with the use of the synthesized alumosilicates. Advanced Materials Research 10223: 6.

13. Loganina VI, Makarova LV, Tarasov RV, Ryzhov AD (2014) The limy composite 
Citation: Loganina VI, Zhegera CV (2017) Use of the Additive Based on Amorphous Silica-Alumina in the Adhesive Dry Mixes. J Material Sci Eng 6: 361. doi: 10.4172/2169-0022.1000361

Page 3 of 3

binder with the use of the synthesized alumosilicates. Applied Mechanics and Materials 662: 11-14

14. Loganina VI, Ryzhov AD (2015) Structure and properties of synthesized additive based onamorphous aluminosilicates. Case Studies in Construction Materials 3: 132-136.

15. Mumpton FA (1999) Larocamagica: Uses of natural zeolites in agriculture and industry. PNAS 96: 7346-7347.

16. Andrejkovicova S, Ferraz L, Velosa AL, Silva AS, Rocha F (2012) Air Lime mortars with incorporation of sepiolite and synthetic zeolite pellets. ActaGeodyn Geomater 9: 79-91.
17. Aiello R, Collela C, Sersale R (1971) Zeolite Formation from Synthetic and Natural Glasses. Advances Chem Ser 101: 51-62.

18. Barrer MR, Cole JF, Sticher H (1968) Chem Soc Inorg Phys Theoret, p: 102475

19. Broussard L, Shoemker DP (1960) The Structures of Synthetic Molecular Sieves. Journal of The A merican Chemical Society 82: 1041-1051.

20. Loganina VI, Tarasov RV, Zhegera KV (2014) Optimization of tile adhesive using synthesized aluminosilicate. Regional architecture and engineering Penza, pp: 44-48. 